\title{
Retrofitting Rural Dwellings in Delta Region to Enhance Climate Change Mitigation in Egypt
}

\author{
Ahmed ABOUAIANA* \\ Department of Planning, Design, and Technology of Architecture, La Sapienza University of Rome, \\ via Flaminia 00169, Rome, Italy
}

\begin{abstract}
The current rural dwelling pattern in the Delta in Egypt consumes much energy to achieve dwellers' thermal comfort, increasing greenhouse gas emissions contributing to climate change threatening the region's coastal parts. Therefore, this study highlights the potential of retrofitting the existing rural house utilizing pervasive construction technologies in diminishing energy consumption and carbon dioxide emissions as a climate change mitigation strategy. The current modern rural house and the construction typologies were characterized. This study selected a typical modern rural dwelling located in Al-Gharbia Governorate in the Delta region. The suggested retrofitting strategies were applied to the external building envelope. The impact on the annual energy consumption of cooling and heating loads was evaluated using an Energy Performance Assessment Tool (Design Builder). An optimal envelope configuration was suggested, then an economic assessment and an investigation to the local acceptance were provided. The results showed that using the commonly used construction techniques as a retrofitting strategy can plummet the energy consumption and $\mathrm{CO}_{2}$ emissions by one-third worthy of mentioning that the locals have shown a lack of interest in the investment in retrofitting their buildings as well as the economic model showed that the investment is not profitable. Further studies can be made by the author considering investigating different building typologies and engaging other stakeholders.
\end{abstract}

Keywords - Economic analysis; energy efficiency; energy simulation tools; modern rural house; passive envelope; social acceptance

\section{INTRODUCTION}

The rural Egyptian village is being reformed due to socio-economic and political aspects, which produced modern rural dwelling pattern with new walls and roofing configuration layers instead of the traditional ones [1]-[5]. These new-fangled building envelopes play a vital role in transferring the thermal load to/from inner spaces, which led to high annual energy consumption due to using cooling and heating systems such as fans and air conditioners to fulfil thermal comfort inside indoor spaces. Consequently, it increases greenhouse gas emissions contributing to climate change.

Globally, climate change has many indirect negative impacts at many levels, such as migration waves, crop productivity reduction, water sensitivity, increases in malnutrition and unemployment rates, and such ecological systems [6]-[10]. In Egypt, it is threatening the Delta region because its coastal areas are the most vulnerable in the world due to sea-level rise [11], and its area of land is declining rapidly [12]. However, Egypt contributes less than

\footnotetext{
* Corresponding author.

E-mail address: ahmed.abouaiana@uniroma1.it 
$0.7 \%$ of the total global carbon dioxide $\left(\mathrm{CO}_{2}\right)$ emissions [13]. It is the uppermost density region and the only agricultural region in Egypt.

Regarding the existing physical planning regions, Egypt has seven regional units, and each one consists of three levels, Governorates, District, and Villages and Satellites.

The Delta one of these regions that consist of five governorates, 106 districts and cities, and 1404 villages [14], with a total area of $12357.4 \mathrm{~km}^{2}$ (2.94) million 'feddans $\dagger^{\text {' }}$ representing about $1.22 \%$ of the total area of Egypt. It has about 16.5 million inhabitants consists of (66\% rural and $34 \%$ urban), representing $21 \%$ of Egypt's total population. The total number of residential buildings is about 3.17 million buildings, represent $94 \%$ of entire buildings. The average annual electricity consumption per inhabitant in Egypt is $2020 \mathrm{kWh}$ [15]. Table 1 shows residential buildings by type and by (urban/rural) of the Delta region.

TABle 1. Buildings Distribution by (TyPe) \& (RURAL/URBAN) In DELTA REgion [16]

\begin{tabular}{lllllll}
\hline \multirow{2}{*}{ Total Buildings } & \multicolumn{2}{l}{ Residential buildings by type } & & \\
\cline { 3 - 6 } & & House/ Apartment & Skyrise & Villa & Chalet & Country House \\
\hline Rural & 2488366 & 1808810 & 0 & 3924 & 860 & 212085 \\
Urban & 678756 & 1017226 & 250 & 4241 & 4374 & 15279 \\
\hline
\end{tabular}

Generally, energy consumption goes hand in hand with $\mathrm{CO}_{2}$ emissions in a positive correlation [17] and [18], as well as energy consumption contains a nearly similar part of $\mathrm{CO}_{2}$ emissions [19]. Reference [20] defined mitigation as 'a human intervention to reduce the sources or enhance the sinks of greenhouse gases.' In this realm, the buildings sector has an essential role in mitigating climate change impact [21]. In this context, passive improvements of the building envelope are considered essential strategies to enhance energy efficiency and thermal comfort [22] and [23].

Locally, Egypt pays considerable attention to the energy efficiency issue; for instance, it is one of the prime strategical goals of the 2030 National Sustainable Development Vision [24]. The Egyptian Residential Buildings' Energy Codes (ERBEC) has been established in 2006, which provides the minimum requirements to improve energy efficiency in existing and new residential buildings for different climatic zones in Egypt [25]. The local rating system Green Pyramid Rating System (GPRS) was launched to assess buildings' sustainability, as well as improving the building envelope is one of its seven parts [26].

Based on these facts and potentials, this study proposes an optimal external envelope design using the pervasive construction materials and technologies as guidelines to reduce energy consumption and to mitigate climate change in the existing rural houses in Delta region.

References [1] and [2] determined the prevailing housing typology in the Delta region. It has been built during the last four decades, surrounded by agricultural areas or urban mass. The range of footprint area is between 80 and $160 \mathrm{~m}^{2}$; the average floor height is 2.90 meters. It consists of two or three floors; it consists of a hall, three rooms, a bathroom, a kitchen, a staircase, a terrace, and, sometimes, a farmyard. Furthermore, the average room area is $14.00 \mathrm{~m}^{2}$. In terms of construction, the roof is constructed of reinforced concrete slab, while the walls are constructed of red brick 12 and $25 \mathrm{~cm}$, elevation finished by cement plaster. The average window to wall ratio (WWR) is $11 \%$. Windows are made of single clear glass $3 \mathrm{~mm}$ with a wooden frame and shading screen.

\footnotetext{
${ }^{\dagger}$ Feddan is unit of area used in Egypt, it equals $4200 \mathrm{~m}^{2}$.
} 


\section{Methodology}

The methodology is divided into four phases. Firstly, a set of simulation runs was conducted for different passive configurations of the wall, roof, and windows using the available construction materials to investigate their impact on the annual cooling and heating energy consumption and $\mathrm{CO}_{2}$ emissions. Secondly, an economic assessment for the different design variables was carried out. Then a comparison between the cost of refurbishment and the reduction in the consumption for all scenarios. Three retrofitting strategies (minor, optimum, and significant) were suggested based on the previous steps. A profitability analysis follows this. Moreover, a structured questionnaire was distributed among the dwellers to examine their awareness and acceptance of the refurbishing process. Finally, Multi-objective criteria were identified.

\section{Original Case Parameters}

A west-oriented room in a typical rural dwelling pattern located in Nawag Village, Gharbiya Governorates, was selected. Room dimensions are $3.40 \times 4.30 \mathrm{~m}$. The interior room height is $2.90 \mathrm{~m}$.

The external wall area is $11.20 \mathrm{~m}$ that consists of $(2 \mathrm{~cm}$ plaster, $12 \mathrm{~cm}$ red brick and $2 \mathrm{~cm}$ plaster). The external roof area is $14.60 \mathrm{~m}$ that consists of a reinforced concrete slab of $15 \mathrm{~cm}$ thickness and $2 \mathrm{~cm}$ plaster from outside to inside. While the window makes up a single clear $3 \mathrm{~mm}$ glass with a wooden frame and a traditional wooden shading screen 'Sheesh' and the WWR is $11 \%$. The building relies on the air conditioning (split unit) for summer cooling. Fig. 1 depicts the traditional 'Sheesh' during manufacturing.

\section{Simulation Model Algorithms}

The above-mentioned parameters were examined using the validated simulation tool, Design Builder version 4.5, as seen in Fig. 2, these tools also significantly optimize energy consumption in the design stage [27] and [28]. A climatic weather file data of Delta was selected. The artificial lighting and the electrical appliances were neglected. The occupancy density is 0.17 people $/ \mathrm{m}^{2}$. The setpoint and the setback degrees of cooling and heating are $25^{\circ}$ and $28^{\circ} \mathrm{C}$, and $21^{\circ}$ and $12^{\circ} \mathrm{C}$. The study assumed that air conditioning was used for winter heating. The inner partitions and floor are considered adiabatic surfaces. The simulation model is available on reference [29].

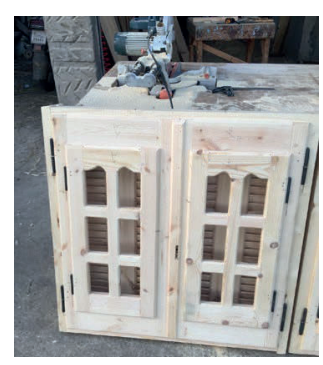

Fig. 1. The Traditional 'Sheesh'. 


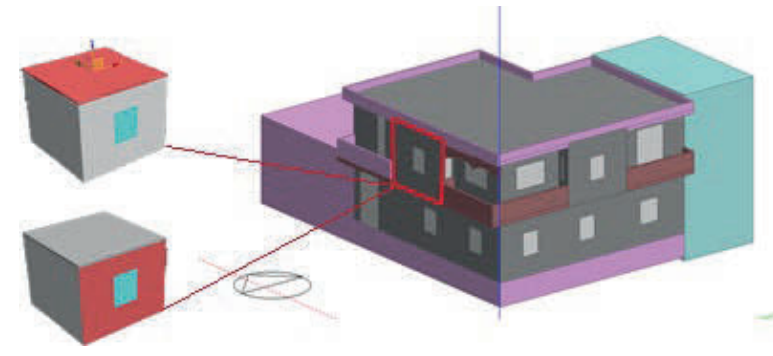

Fig. 2. The Simulation Model Extracted Room Design Builder.

A set of passive retrofitting variables were proposed and applied on:

- opaque parts: based on different thermal properties $R$-value of construction materials and used insulation;

- transparent parts: based on different thermal properties and solar heat gain coefficient SHGC of glazing types. Table 2 summarizes the suggested design variables.

\section{TABLE 2. The Proposed Design VARIABLES}

\begin{tabular}{ll}
\hline Design Variables & Description \\
\hline Wall types & Redbrick $(12 \times 25 \times 38 \mathrm{~cm})$ thickness, and a mud-brick wall $40 \mathrm{~cm}$ thickness \\
Wall insulation & Insulated cored red brick $25 \mathrm{~cm}$ and (EPS), thickness from $1-10 \mathrm{~cm}$ \\
Window Glazing type & Single Clear Glass $(3 \mathrm{~mm}$, and $6 \mathrm{~mm})$, and double Clear Glass $6 \mathrm{~mm}$ with $13 \mathrm{~mm}$ Air \\
WWR & $10 \%, 20 \%$ and $30 \%$ \\
Shading Screen & Shading screen $(\mathrm{SC})$ used, and without (SC) \\
Roof type & Reinforced concrete $(\mathrm{RC})$ slab $15 \mathrm{~cm}$ thickness, and RC slab with cement tiles $5 \mathrm{~cm}$ thick \\
Roof insulation & RC slab and cement tiles $5 \mathrm{~cm}$ with various foam insulation thicknesses from $1-10 \mathrm{~cm}$ \\
\hline
\end{tabular}

\subsection{External Wall Types' Influence}

Firstly, four simulation runs were carried out, one for the base case (red brick $12 \mathrm{~cm}$ ). The other three retrofitting alternatives are $25 \mathrm{~cm}$ red brick, $38 \mathrm{~cm}$ red brick, and $40 \mathrm{~cm}$ mud brick, considering that the roof is an adiabatic surface. Simultaneously, the window consists of a single clear glass $3 \mathrm{~mm}$, wooden frame and shading screen with WWR $10 \%$ with a $U$-Value of $5.894 \mathrm{~W} / \mathrm{m}^{2} \mathrm{~K}$. Table 3 shows the $U$-Value of different wall section types extracted from Design Builder.

\section{TABle 3. The U-VAlue of the Different Wall Construction Types IN W/M²K}

\begin{tabular}{ll}
\hline Wall Construction layers from outer to inner & $U$-Value \\
\hline 0.02 m cement plaster $+0.12 \mathrm{~m}$ red brick $+0.02 \mathrm{~m}$ cement plaster (Base Case) & 2.545 \\
$0.02 \mathrm{~m}$ cement plaster $+0.25 \mathrm{~m}$ red brick $+0.02 \mathrm{~m}$ cement plaster & 1.826 \\
$0.02 \mathrm{~m}$ cement plaster $+0.38 \mathrm{~m}$ red brick $+0.02 \mathrm{~m}$ cement plaster & 1.424 \\
Mud-brick wall $40 \mathrm{~cm}$ & 0.665 \\
\hline
\end{tabular}

The base case results have recorded $319 \mathrm{kWh}$ of energy consumption and $193 \mathrm{CO}_{2}$ emissions. While altering the wall type to red brick $(25 \mathrm{~cm}$ and $38 \mathrm{~cm})$ decreased the energy consumption and the emissions by $16 \%$ and $27 \%$, respectively, compared to the base case, utilizing a mud-brick wall reduced the consumption and emissions significantly by $44 \%$. 
Fig. 3 illustrates the simulation results of the annual electricity consumption and $\mathrm{CO}_{2}$ emissions of different wall types due to cooling and heating loads.

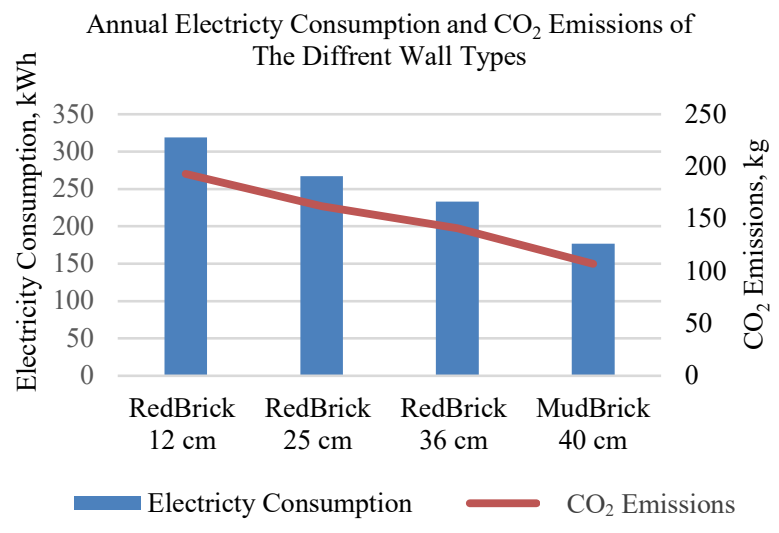

Fig. 3. Annual Electricity Consumption and $\mathrm{CO}_{2}$ Emissions for Wall Section Pre and Post Retrofitting.

\subsection{Walls' Insulation Thicknesses Influence}

Secondly, to evaluate the impact of the different insulation thicknesses as retrofitting solutions, different wall section types on the annual electricity and $\mathrm{CO}_{2}$ emissions of cooling and heating loads. A set of ten simulation runs took place. The cases consist of a cored red brick wall of $25 \mathrm{~cm}$ with a variable EPS insulation 1 to $10 \mathrm{~cm}$. The roof is an adiabatic surface, while the window consists of a single clear glass $3 \mathrm{~mm}$, wooden frame, and shading screen with WWR $10 \%$ with a $U$-Value of $5.894 \mathrm{~W} / \mathrm{m}^{2} \mathrm{~K}$ for wall section before and after retrofitting. Table 4 shows the $U$-Value of the interventions.

Table 4. The U-Value of The Different Wall Insulation Thicknesses IN W/M²K)

\begin{tabular}{lllllllllll}
\hline Base & \multicolumn{10}{l}{ EPS insulation thickness (added to cored red brick wall $25 \mathrm{~cm}$ ) } \\
\cline { 2 - 13 } 2.545 & 1.273 & $2 \mathrm{~cm}$ & $3 \mathrm{~cm}$ & $4 \mathrm{~cm}$ & $5 \mathrm{~cm}$ & $6 \mathrm{~cm}$ & $7 \mathrm{~cm}$ & $8 \mathrm{~cm}$ & $9 \mathrm{~cm}$ & $10 \mathrm{~cm}$ \\
& 1.966 & 0.778 & 0.651 & 0.560 & 0.491 & 0.437 & 0.394 & 0.359 & 0.329 \\
\hline
\end{tabular}

The results showed that adding a layer of $1 \mathrm{~cm}$ EPS to the cored $25-\mathrm{cm}$ red brick reduced one-third of consumption and emissions compared to the base case, by adding layers of 2, 3, and $4 \mathrm{~cm}$ EPS decreased more $12 \%, 9 \%$, and $7 \%$ respectively. While adding (5 and 6) $\mathrm{cm}$ of the EPS decreased another $5 \%$ and $4 \%$. It is evident that with every additional $1 \mathrm{~cm}$ insulation, the consumption rate decreases gradually to reach almost the same results. Thus, a layer of $5 \mathrm{~cm}$ insulation can be considered as the optimal thickness. Fig. 4 shows the total annual energy consumption and $\mathrm{CO}_{2}$ emissions of the wall sections pre- and post-retrofitting using different insulation thicknesses. 


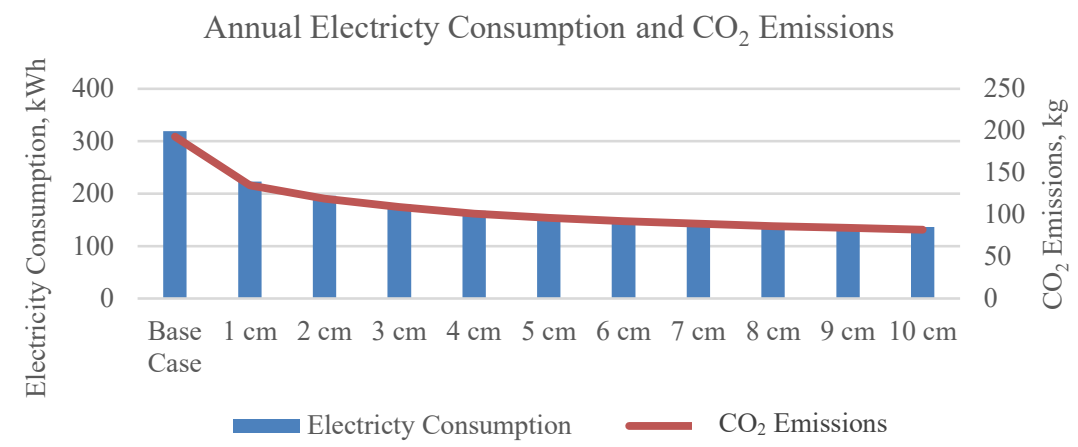

Fig. 4. Total Electricity Consumption and $\mathrm{CO}_{2}$ Emissions Results for Wall Construction Layers Simulation Runs.

\subsection{Roof Insulation Influence}

Thirdly, in order to evaluate the impact of the roof on the energy consumption and $\mathrm{CO}_{2}$ emissions. The simulation examined a set of twelve roof scenarios; the first is the base case before retrofitting, consisting of $(2 \mathrm{~cm}$ cement plaster and $15 \mathrm{~cm}$ reinforcement concrete slab). In the second, two layers of $5 \mathrm{~cm}$ cement tiles and $5 \mathrm{~cm}$ mortar were added, while in the other ten solutions, layers of foam insulation with varies thicknesses from $1 \mathrm{~cm}$ to $10 \mathrm{~cm}$. Table 5 shows the $U$-Value of all scenarios pre and post retrofitting.

TABle 5. Roof Insulation Thermal Properties (U-VAlue IN W/M²K)

\begin{tabular}{llll}
\hline \multicolumn{4}{c}{ EPS insulation line thickness } \\
\hline Base case & 0.909 & $5 \mathrm{~cm}$ & 0.407 \\
N/A & 0.828 & $6 \mathrm{~cm}$ & 0.369 \\
$1 \mathrm{~cm}$ & 0.628 & $7 \mathrm{~cm}$ & 0.338 \\
$2 \mathrm{~cm}$ & 0.586 & $8 \mathrm{~cm}$ & 0.312 \\
$3 \mathrm{~cm}$ & 0.511 & $9 \mathrm{~cm}$ & 0.289 \\
$4 \mathrm{~cm}$ & 0.453 & $10 \mathrm{~cm}$ & 0.270 \\
\hline
\end{tabular}

The results showed that adding cement flooring tiles on a cement mortar to the reinforcement concrete slab reduced only $3 \%$ compared to the base case. Moreover, adding 1,2 , and $3 \mathrm{~cm}$ of foam reduced more $12 \%, 10 \%, 9 \%$, respectively, while by adding $4 \mathrm{~cm}$, the consumption dropped by $13 \%$ compared to the previous values. It is evident that with every additional $1 \mathrm{~cm}$ insulation, the consumption rate reduces progressively to reach nearly results. Therefore, a layer of $4 \mathrm{~cm}$ insulation can be considered as the optimal thickness. Fig. 5 illustrates the total annual energy consumption and $\mathrm{CO}_{2}$ emissions of the roof sections before and after retrofitting using cement flooring tiles with insulation and without. 


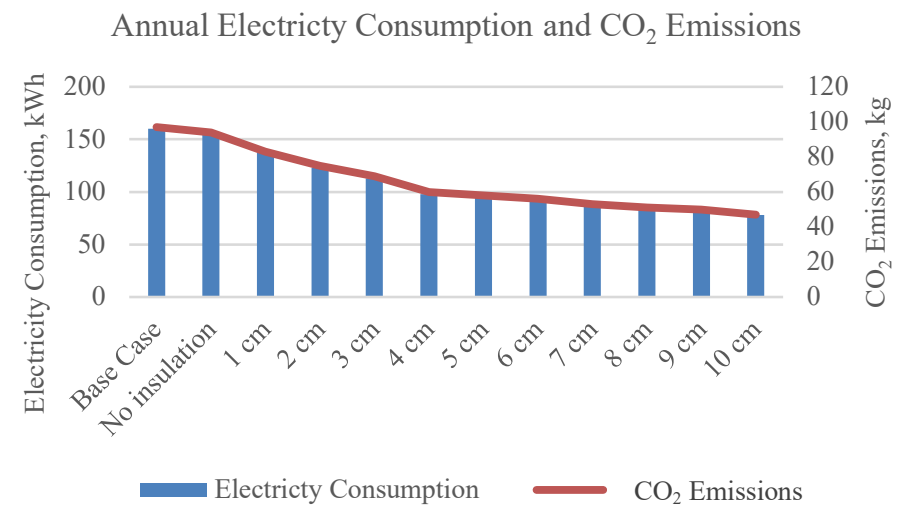

Fig. 5. Total Electricity Consumption and $\mathrm{CO}_{2}$ emissions for Roof Construction Layers Simulation Runs.

\subsection{Fenestration Influence}

Three simulation runs were carried out to assess the impact of different glazing types on the annual electricity and $\mathrm{CO}_{2}$ emissions of cooling and heating loads. The first is for the window, using a single clear glass $3 \mathrm{~mm}$ thickness with a wooden frame and without a shading screen; the others are single clear glass $6 \mathrm{~mm}$ thickness, and double clear glass $6 \mathrm{~mm}$ with $13 \mathrm{~mm}$ air in-between. Considering the roof is an adiabatic surface, WWR $10 \%$, and the wall section is $12 \mathrm{~cm}$ red brick. Table 6 shows the $U$-Value and the Solar Heat Gain coefficient (SHGC) of the different glazing types.

TABle 6. Roof Insulation Thermal Properties (U-Value IN W/M²K)

\begin{tabular}{lccc}
\hline & $3 \mathrm{~mm}$ Single clear glass & $6 \mathrm{~mm}$ Single clear glass & $6 \mathrm{~mm}$ Double clear glass / $13 \mathrm{~mm}$ Air \\
\hline SHGC & 0.861 & 0.819 & 0.703 \\
$U$-Value & 5.894 & 5.778 & 2.665 \\
\hline
\end{tabular}

The single clear glass $3 \mathrm{~mm}$ achieved the highest consumption and $\mathrm{CO}_{2}$ emissions by $393 \mathrm{kWh}$ and $238 \mathrm{~kg}$. By using the single clear $6 \mathrm{~mm}$ glass has no impact on both energy consumption and emissions. While using $6 \mathrm{~mm}$ double clear glass with $13 \mathrm{~mm}$ air, reduced energy and emissions by $14 \%$.

In contemplation of assessing the impact of different WWR $10 \%, 20 \%$, and $30 \%$, one using a local shading screen 'sheesh' and the other without shading screen on the annual electricity consumption $\mathrm{CO}_{2}$ emissions. A set of six simulation runs were implemented. Considering the roof is an adiabatic surface, the wall section is $12 \mathrm{~cm}$ red brick, and the glazing type is $3 \mathrm{~mm}$ single clear glass.

To assess WWR $10 \%$ 's impact on the electricity consumption and $\mathrm{CO}_{2}$ emissions, the base case with shading screen recorded $393 \mathrm{kWh}$ and $238 \mathrm{~kg}$. While adding the shading screen decreased $19 \%$ of the energy consumption and the $\mathrm{CO}_{2}$ emissions.

By altering WWR to $20 \%$, the energy consumption and $\mathrm{CO}_{2}$ emissions recorded $522 \mathrm{kWh}$ and $316 \mathrm{~kg}$, respectively, with an increase of $25 \%$ in energy consumption and $\mathrm{CO}_{2}$ emissions than the same circumstances of WWR $10 \%$. Meanwhile, by adding a shading screen to WWR $20 \%$, the energy consumption and $\mathrm{CO}_{2}$ emissions dropped by $34 \%$.

Eventually, by changing WWR to $30 \%$, the energy consumption and $\mathrm{CO}_{2}$ emissions recorded the highest results by $661 \mathrm{kWh}$ and $401 \mathrm{~kg}$, respectively, with an increase of $41 \%$ 
in energy consumption and $\mathrm{CO}_{2}$ emissions in the same circumstances of the WWR $10 \%$. While adding shading screen to WWR $30 \%$ reduced the energy consumption and $\mathrm{CO}_{2}$ emissions by $44 \%$. Fig. 6 summarizes the results of the six simulation runs of different WWR and shading screen strategies.

Annual Electricty Consumption and $\mathrm{CO}_{2}$ Emissions

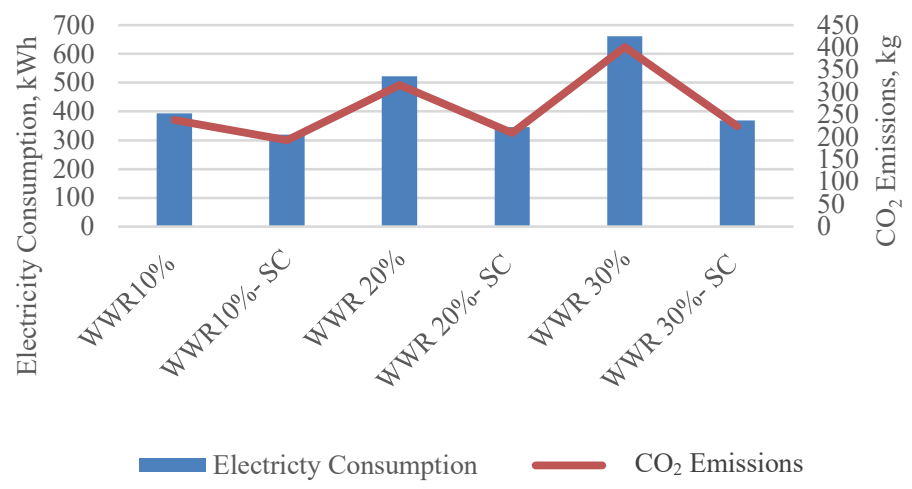

Fig. 6. Total Electricity Consumption and $\mathrm{CO}_{2}$ emissions for the Different WWR and Shading Screens Scenarios.

\subsection{Discussion of Simulation Results}

A group of design variables for building envelope was investigated separately. In order to optimize the building envelope, a suggested retrofitting solution is recommended that can decrease the annual energy consumption and $\mathrm{CO}_{2}$ emissions efficiently.

Firstly, for the wall section, altering the original wall to $25 \mathrm{~cm}$ red brick reduced annual $\mathrm{CO}_{2}$ emissions and energy consumption by $16 \%$; it is considered a minor renovation. While adding an insulation layer of the EPS $5 \mathrm{~cm}$ to the cored wall decreased the consumption by one-half. The higher insulation values decreased energy almost likely; thus, it is considered the optimum thickness. Finally, the maximum reduction was achieved (136 kWh) using a layer of EPS 10, which beheld the major renovation.

Likewise, adding cement flooring tiles and mortar to the original roof configurations reduced the energy by $4 \%$ for the roof. Withal adding a layer of $5 \mathrm{~cm}$ foam thickness lessened the consumption by $38 \%$, the higher insulation values almost likely decreased, so it beheld the optimal strategy $\$$. In contrast, the uppermost reduction attained by utilizing $10 \mathrm{~cm}$ foam by $78 \mathrm{kWh}$, which is considered the major one.

Finally, the original window configuration ( $3 \mathrm{~mm}$ single clear glass, WWR $10 \%$, and Shading Screen) recorded the lowest energy consumption results, so it is considered the optimal configuration in all scenarios.

In the final analysis, four simulation runs were conducted, one for the base case's entire envelope and the others for the recommended (minor, optimal, and significant) refurbishment scenarios. The base case results recorded $442 \mathrm{kWh}$ energy consumption and $268 \mathrm{~kg} \mathrm{CO}_{2}$. Table 7. summarizes the energy and $\mathrm{CO}_{2}$ consumptions of the proposed bare and optimum wall and roof layers configurations.

\footnotetext{
\$ Another factor supports applying $5 \mathrm{~cm}$ thickness of the insulation materials to the wall and the roof. The majority of the local suppliers provide it as a typical insulation solution, regardless of the essential needs and technical studies.
} 
TABle 7. ENERGy CONSUMPTION AND $\mathrm{CO}_{2}$ EMissions PRE AND Post ENVELOPE RetrofitTing

\begin{tabular}{|c|c|c|c|c|c|c|}
\hline \multicolumn{3}{|c|}{ Different Design Variables of the Envelope } & \multicolumn{2}{|c|}{$\begin{array}{c}\text { Different Retrofitting } \\
\text { Scenarios Consumption }\end{array}$} & \multicolumn{2}{|c|}{$\begin{array}{c}\text { Saving compared to the } \\
\text { Base Case }\end{array}$} \\
\hline Wall & Window & Roof & Energy & $\mathrm{CO}_{2}$ & Energy & $\mathrm{CO}_{2}$ \\
\hline \multicolumn{7}{|c|}{ Base Case } \\
\hline Red brick $12 \mathrm{~cm}$ & $\begin{array}{l}3 \mathrm{~mm} \mathrm{Sgl} \mathrm{Clr}+ \\
\mathrm{SC}+\mathrm{WWR} 10 \%\end{array}$ & $\mathrm{RC}+$ Cement Tiles & $442 \mathrm{kWh}$ & $268 \mathrm{~kg}$ & N/A & N/A \\
\hline \multicolumn{7}{|c|}{ Scenario 1} \\
\hline Red brick $25 \mathrm{~cm}$ & $\begin{array}{l}3 \mathrm{~mm} \mathrm{Sgl} \mathrm{Clr}+ \\
\mathrm{SC}+\mathrm{WWR} 10 \%\end{array}$ & $\mathrm{RC}+$ Cement Tiles & $318 \mathrm{kWh}$ & $192 \mathrm{~kg}$ & $28 \%$ & $28 \%$ \\
\hline \multicolumn{7}{|c|}{ Scenario 2} \\
\hline $\begin{array}{c}\text { Cored red brick } 25 \mathrm{~cm} \\
+ \text { EPS } 5 \mathrm{~cm}\end{array}$ & $\begin{array}{l}3 \mathrm{~mm} \mathrm{Sgl} \mathrm{Clr}+ \\
\mathrm{SC}+\mathrm{WWR} 10 \%\end{array}$ & $\begin{array}{c}\mathrm{RC}+\text { Cement Tiles }+ \\
5 \mathrm{~cm} \text { Foam }\end{array}$ & $206 \mathrm{kWh}$ & $125 \mathrm{~kg}$ & $34 \%$ & $34 \%$ \\
\hline \multicolumn{7}{|c|}{ Scenario 3} \\
\hline $\begin{array}{c}\text { Cored red brick } 25 \mathrm{~cm} \\
+ \text { EPS } 10 \mathrm{~cm}\end{array}$ & $\begin{array}{l}3 \mathrm{~mm} \mathrm{Sgl} \mathrm{Clr}+ \\
\mathrm{SC}+\mathrm{WWR} 10 \%\end{array}$ & $\begin{array}{c}\mathrm{RC}+\text { Cement Tiles }+ \\
10 \mathrm{~cm} \text { Foam }\end{array}$ & $170 \mathrm{kWh}$ & $103 \mathrm{~kg}$ & $40 \%$ & $40 \%$ \\
\hline
\end{tabular}

\section{ECONOMIC ASSESSMENT}

Regarding the local market and reference [30], the conventional envelope's supply-and-apply price for the wall and roof was identified. Firstly, for the wall, the cost of red bricks $(0.25 \times 0.12 \times 0.06 \mathrm{~m})$, the 1000 red brick costs about 2000 Egyptian Pounds (EGP), the 1000 brick gives $17 \mathrm{~m}^{2}$. Thus, the meter square costs about 120 EGP and 90 EGP for two layers of $2 \mathrm{~cm}$ cement plaster thicknesses, so the meter square costs around $210 \mathrm{EGP}$.

While estimating the cost of retrofitting solution of $5 \mathrm{~cm}$ EPS insulation layer; the meter cubic costs around 1550 EGP, which gives twenty slices of $5 \mathrm{~cm}$-thick sheets, so the meter square costs 75 EGP. To conclude, the entire retrofitted wall consists of a cored wall with $5 \mathrm{~cm}$ EPS in-between costs about 495 EGP. The differentiation between the cost of the wall before and after retrofitting is 285 EGP.

Secondly, the cost of $1 \mathrm{~m}^{2}$ wooden window thickness $2.54 \mathrm{~cm}$ ( 1 inch) is 1750 EGP as seen in Fig. 1, the price includes glass, accessories, and the painting.

Thirdly, the cubic meter of reinforcement concrete (RC) slab costs about 3500 EGP. The slab thickness equals $0.15 \mathrm{~m}$, and the entire roof's room area is $14.6 \mathrm{~m}^{2}$, which equals $2.2 \mathrm{~m}^{3}$ of a reinforced concrete slab. To estimate the price of the retrofitted roof, adding $5 \mathrm{~cm}$ concrete tiles on a $5 \mathrm{~cm}$ mortar costs $100 \mathrm{EGP}$, in addition to $85 \mathrm{EGP}$ for $5 \mathrm{~cm}$ foam; thus, the differentiation between the original roof and the retrofitted solution is 185 EGP.

Fourthly, the cost of electricity consumption reduction based on the electricity price was determined. The tariff of $1 \mathrm{kWh}$ in Egypt varies from 0.38 to 1.40 EGP based on the seven consumption segments, for instance, the cost of the kWh costs 0.48 EGP in the third segment, which ranges between 0 and $200 \mathrm{kWh}$ monthly. The base case's real monthly consumption is collected from the owner's electricity bills, and it is between 201 and $350 \mathrm{kWh}$ - the fourth segment. Table 8 summarises the cost of the suggested retrofitting variables.

Table 8 shows the price of annual savings due to different retrofitting scenarios. The cost variation between retrofitting scenarios (1,2, and 3) and the base case are 1320, 2157, and 3094 EGP, respectively, which is considered the cash of investment. In parallel, the cost of the annual saving in energy for these scenarios compared to the base case's consumption are 124, 236, and $272 \mathrm{kWh}$, as seen in Table 9, which costs 122, 231, and 267 EGP, considering the consumption segment Tarif 0.98 EGP. 


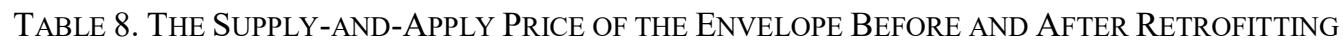

\begin{tabular}{|c|c|c|c|c|}
\hline Item & Unit & Quantity & Unit Price, EGP & Total, EGP \\
\hline \multicolumn{5}{|l|}{ Base Case } \\
\hline $12 \mathrm{~cm}$ red brick wall & $\mathrm{m}^{2}$ & 10 & 210 & 2100 \\
\hline $\mathrm{RC}$ Slab $+2 \mathrm{~cm}$ cement plaster & $\mathrm{m}^{3}$ & 2.2 & 3500 & 7700 \\
\hline Windows Sgl Clr 3 mm + SC (WWR $10 \%$ ) & $\mathrm{m}^{2}$ & 1.20 & 1700 & 2040 \\
\hline TOTAL & & & & 11840 \\
\hline \multicolumn{5}{|l|}{ Scenario 1} \\
\hline $25 \mathrm{~cm}$ red brick Wall + EPS $5 \mathrm{~cm}$ & $\mathrm{~m}^{2}$ & 10 & 320 & 3200 \\
\hline Roof + Tiles & $\mathrm{m}^{3}$ & 2.2 & 3600 & 7920 \\
\hline Windows Sgl Clr 3 mm + SC (WWR $10 \%$ ) & $\mathrm{m}^{2}$ & 1.20 & 1700 & 2040 \\
\hline TOTAL & & & & 13160 \\
\hline \multicolumn{5}{|l|}{ Scenario 2} \\
\hline Wall+ EPS $5 \mathrm{~cm}$ & $\mathrm{~m}^{2}$ & 10 & 385 & 3850 \\
\hline Roof + Cement Tiles + Foam $5 \mathrm{~cm}$ & $\mathrm{~m}^{3}$ & 2.2 & 3685 & 8107 \\
\hline Windows Sgl Clr 3 mm + SC (WWR $10 \%$ ) & $\mathrm{m}^{2}$ & 1.20 & 1700 & 2040 \\
\hline TOTAL & & & & 13997 \\
\hline \multicolumn{5}{|l|}{ Scenario 3} \\
\hline $25 \mathrm{~cm}$ red brick Wall + EPS $10 \mathrm{~cm}$ & $\mathrm{~m}^{2}$ & 10 & 460 & 4600 \\
\hline Roof + Tiles + Foam $10 \mathrm{~cm}$ & $\mathrm{~m}^{3}$ & 2.2 & 3770 & 8294 \\
\hline Windows Sgl Clr 3 mm + SC (WWR $10 \%$ ) & $\mathrm{m}^{2}$ & 1.20 & 1700 & 2040 \\
\hline TOTAL & & & & 14934 \\
\hline
\end{tabular}

Many studies discussed the financial and economic analysis to provide a multicriteria optimization of the retrofitting process using different techniques and approaches, such as [31]-[35]. Net Present Value (NPV) model is one of 25 commonly used models in building energy evaluation [36].

NPV is the present value of anticipated cash inflows associated with the project less the present value of the project's expected cash outflows, discounted at the appropriate cost of capital, it is used to assess such a project's profitability ${ }^{\S}$, represented by Eq. (1) [37].

$$
\sum_{t=0}^{N} \frac{C F_{t}}{(1+r)^{t}}
$$

where:

$C F_{t}$ the expected net cash flow at time $t$ represents the investment amount in retrofitting the envelope (annual saving due retrofitting);

$N \quad$ the estimated life of the investment;

$r$ the discount rate (opportunity cost of capital). In this study $r$ equals the annual interest rate of $0.825 \%$ regarding the Central Bank of Egypt [38].

If the results give a negative value, it means the project is not profitable and vice versa; positive values mean it is profitable in a particular year. Table 9 summarises the equation parameters.

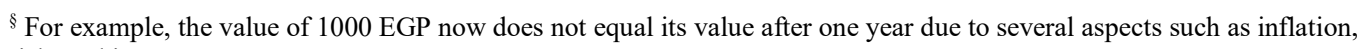
risk, and interest rate. 
TABLE 9. VARIATION'S COST OF RETROFITTING AND THE ANNUAL SAVING OF ELECTRICITY

\begin{tabular}{llllll}
\hline Scenario & $\begin{array}{l}\text { Retrofit cost's } \\
\text { variation compared } \\
\text { to the base case }\end{array}$ & $\begin{array}{l}\text { Annual saving } \\
\text { due to Retrofitting }\end{array}$ & $\begin{array}{l}\text { Consumption } \\
\text { Segment Tarif of } \\
\text { the } \mathrm{kWh}\end{array}$ & $\begin{array}{l}\text { Annual saving } \\
\text { due to Retrofitting } \\
\left(C F_{t}\right)\end{array}$ & $\begin{array}{l}\text { positive results' } \\
\text { achieving year of } \\
\text { NPV }\end{array}$ \\
\hline Scenario 1 & $1320 \mathrm{EGP}$ & $124 \mathrm{kWh}$ & $0.98 \mathrm{EGP}$ & $122 \mathrm{EGP}$ & The $29^{\text {th }}$ Year \\
Scenario 2 & $2157 \mathrm{EGP}$ & $236 \mathrm{kWh}$ & $0.98 \mathrm{EGP}$ & $231 \mathrm{EGP}$ & The $19^{\text {th }}$ Year \\
Scenario 3 & $3094 \mathrm{EGP}$ & $272 \mathrm{kWh}$ & $0.98 \mathrm{EGP}$ & $267 \mathrm{EGP}$ & The $40^{\text {th }}$ Year \\
\hline
\end{tabular}

By applying the equation [39] for the first scenario, the initial investment is $1320 \mathrm{EGP}$, and the cash flow is 122 EGP; the results showed the profitability would be achieved in the twenty-ninth year. In the second scenario, the initial investment is 2157 EGP, and the annual cash flow is 231 EGP; the profitability would be achieved in the nineteenth year. Then, at the initial cost of 3094 EGP and cash flow, 267 EGP achieved profitability in the fortieth year.

\section{DWELlers InVOLVEMENT}

In a similar context, the architect Hassan Fathy in his role model of Al Gourna Village development in the 1960s, emphasized the importance of engaging locals in retrofitting and development processes because the inhabitants did not accept these strategies [40]. Many studies discussed the social acceptance for different related-energy retrofitting technical solutions in many contexts to measure inhabitants satisfaction [41]-[44] or clients expectations [45].

To investigate the acceptance of the proposed retrofitting strategies, Lasaifar Al-Balad village in Kafr El-Shiekh Governorate was selected for many reasons. It represented a typical village pattern out of 1404 villages in the Delta region. It has the same dwellings typology, and, finally, the author examines other factors within his Ph.D. thesis.

A sample of 31 inhabitants ${ }^{* *}$ represented 31 families was selected. Personal meetings with four of them were implemented as a pilot test stage to adapt and ensure the clearness of the questions. A structured questionnaire (Google Form) [46] was distributed to two private groups of the village on Facebook. The investigation was implemented in the third week of January 2021.

The questionnaire was divided into two groups. Firstly, the close-ended, to identify the sample dwellers characteristics and dwellings typology. Secondly, a mix of closed-ended and the open-ended part to assess their awareness about the climate change issue, examine the liaison between houses and thermal comfort in summer and winter, inspect their acceptance of retrofitting process in terms of the technical and economic perspectives, eventually, an optional question to examine their point of view.

The results of detecting the sample can be seen in Fig. 7, where the pie charts tell us that most dwellings are located on the urban mass. The three-story buildings have prevailed by $43 \%$, followed by the two-floor and more than three-floor by $29 \%$ and $18 \%$, and $10 \%$ has one floor. $57 \%$ of the buildings are for one extended family. Their units are distributed on the ground, in-between, and the last floor equally. Most of them with an average area between 70 and $150 \mathrm{~m}^{2}$, while $22 \%$ have a range between 200 and $250 \mathrm{~m}^{2}$. The bulk is relying on cooling devices in summer; namely, fans and air conditioning by $90 \%$ and $10 \%$ correspondingly, on the contrary, $76 \%$ do not utilize such device for winter heating while $24 \%$ are using heaters and only $6 \%$ use air conditioning for heating.

\footnotetext{
${ }^{* *}$ Regarding the official census 2006 the number of inhabitants is 8589 .
} 
The graphs in Fig. 8 tell us that respondents preponderance lacked awareness of climate change issues by $71 \%$ bar a few linked it is to the agriculture waste and the garbage. In comparison, $29 \%$ identified climate change. In terms of thermal comfort, one-third feel comfort in their dwellings, $15 \%$ responded moderately, and one-half expressed a lack of comfort in summer and winter. It is worth mention that $6 \%$ recognized the relationship between the unit's position and thermal comfort, namely moderate on the ground floor and scorching and cold on the last floor in terms of the exposed roof to climatic conditions.

In connection with technical retrofitting acceptance, the minority responded by the probability, while $87 \%$ agreed. The acceptance dropped to $48 \%$ in the economic realm, while one-third declined to invest in retrofitting, and $22 \%$ responded 'Maybe.' In the optional question, two of those who answered 'Maybe' highlighted the private sector's importance in funding this kind of project. Then, they can pay long-term monthly installments instead of the initial cost. Only one respondent proposed 'what needed is unifying is elevation's colours integrated with the photovoltaic cells and to cover the open sewage canals to reduce their negative impacts'.
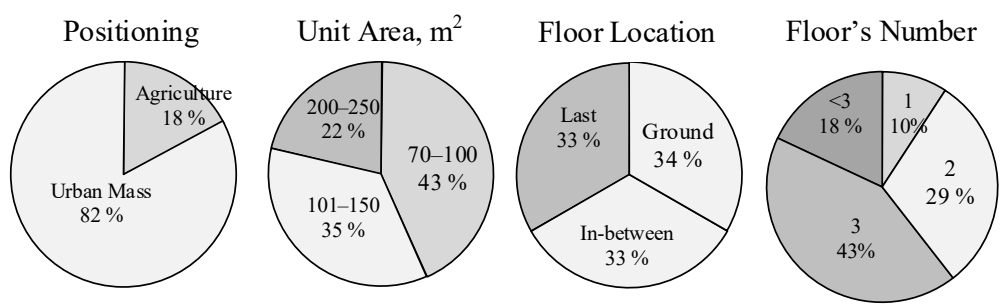

Building Type
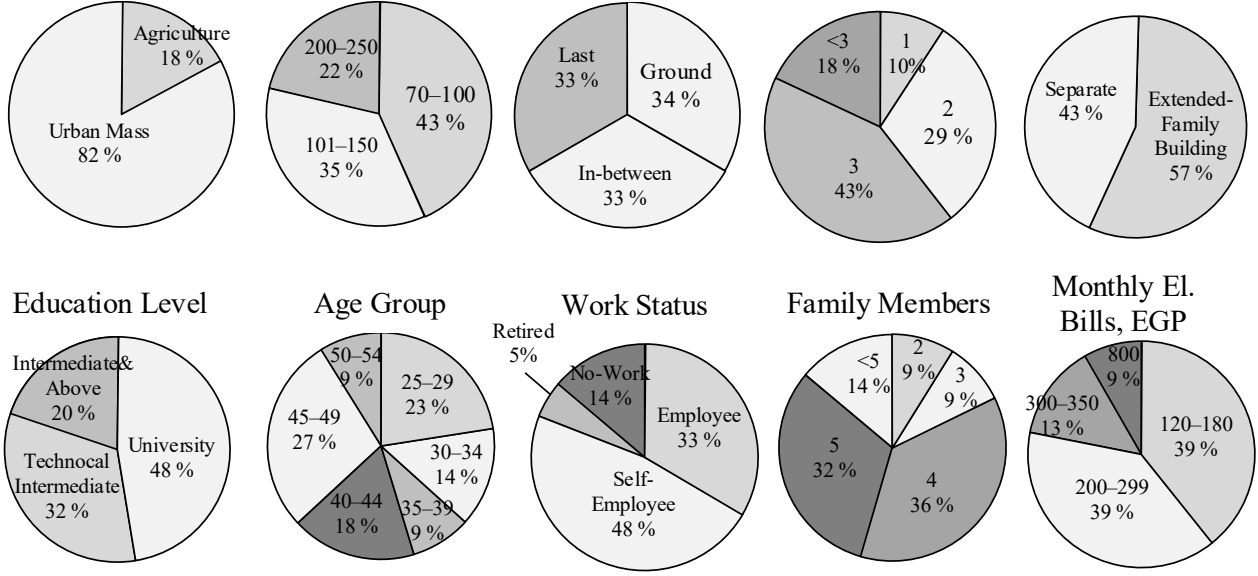

Fig. 7. The results of respondents' characteristics and their dwellings' patterns.
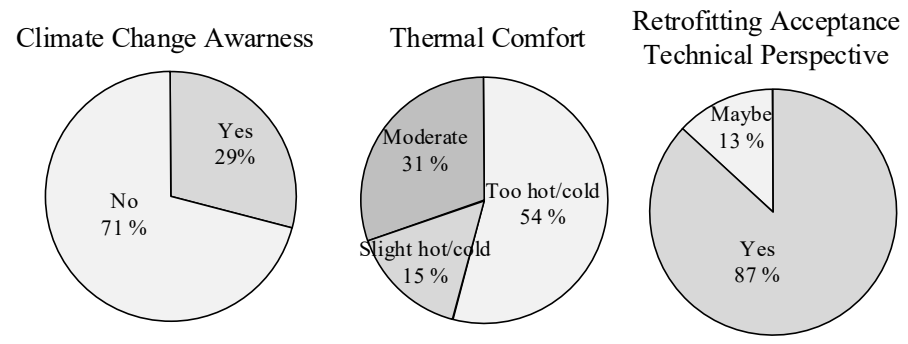

Retrofitting Acceptance Economic Perspective

Fig. 8. The results of the open-ended questions.

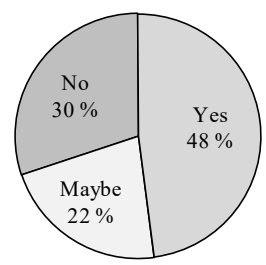




\section{Conclusions}

This study investigated the impact of using available construction materials in the building envelope on the annual operating energy consumption and $\mathrm{CO}_{2}$ emissions of an existing typical dwelling typology in the Delta region. A set of passive retrofitting strategies were conducted on a west-oriented room in a typical modern dwelling in the Delta Region using an energy performance assessment tool, Design Builder.

Three suggested retrofitting strategies were provided and evaluated from technical and price perspectives. The results have been proven that altering the envelope to another configuration without insulation, namely $(25 \mathrm{~cm}$ red brick and adding cement flooring tiles) lessened energy consumption and $\mathrm{CO}_{2}$ emissions by $28 \%$. While adding $5 \mathrm{~cm}$ of insulation in the roof and wall reduced $34 \%$, eventually doubling the insulation layer decreased the highest amount by $40 \%$.

The existing window configuration recorded the lowest energy consumption; moreover, the 'Sheesh' is considered an energy-efficient solution because consumption's variation between the WWR $10-20 \%$ and $20-30 \%$ is neglectable. That sheds light on conventional materials' role in increasing energy efficiency notably.

Regarding the economic analysis, the NPV model proved the investment in the three refurbishment strategies is unprofitable; however, the second scenario achieved profitability in the shortest period by 19 years, followed by the first and third scenarios: 29 and 40 years, respectively. Thus, the second scenario can be considered the most efficient one. What highlighted the importance of considering is the beyond-technical solutions.

Regarding the on-site investigation, a group of population samples with a different characteristics responded to an online questionnaire. One-third showed a significant awareness level towards climate change. The results supported the study's argument that existing dwellings patterns in the Delta region do not meet thermal comfort requirements. The majority agreed to refurbish their buildings from a technical standpoint, vice-versa from the economic perspective, which reflected a potential of locals' acceptance to such development in the Delta region.

Another prospective benefit would be considered based on the low amount of consumed energy 200-350 kWh monthly, compared to the urban context, namely, harvesting renewable energy that would drastically reduce energy consumption and $\mathrm{CO}_{2}$ emissions.

To conclude, the study provided multi-objective optimization criteria, from technical, financial, and social perspectives based on utilizing pervasive construction materials in the local market that can provide retrofitting guidelines to existing buildings to mitigate climate change. The author believes that further optimizing studies to widen the subject would be beneficial to examine different rural building typologies, including early design stages and new construction, and involve decision-makers.

\section{REFERENCES}

[1] Abouaiana A. A. A. Principles for Existing Rural House Sustainability in Delta Region (With Special Reference to Energy Efficiency). Master of Science thesis, Cairo University, 2016. https://doi.org/10.13140/RG.2.2.21412.71044 (In Arabic)

[2] Allam A. K., Amer I. A. Rural housing in the Egyptian village. The Anglo Egyptian Bookshop, 2001. (In Arabic)

[3] Mahgoub Y. The Transformation of Rural Settlements and Dwellings in Egypt. 2016. https://doi.org/10.13140/RG.2.1.4826.1204

[4] Mahgoub Y. The Transformation of Traditional Rural Settlements in Egypt. Presented at the $2^{\text {nd }}$ International Symp. On Built. Environ. New Millenn. Defin. Princ. Prof. Pract. Amasya, Turkey, 2001.

[5] Elsaid M. A. Planning for sustainable rural development in Egypt. Cairo: Ain Shams University, 2007. 
[6] Smith J. B., et al. Egypt's economic vulnerability to climate change. Climate Research 2014:62:59-70. https://doi.org/10.3354/cr01257

[7] Abutaleb K. A. A., et al. Climate Change Impacts, Vulnerabilities and Adaption Measures for Egypt's Nile Delta. Earth Systems and Environment 2018:2:183-192. https://doi.org/10.1007/s41748-018-0047-9

[8] Aboulnaga M. M., Elwan A. F., Elsharouny M. R. Urban Climate Change Adaptation in Developing Countries. Springer, 2019. https://doi.org/10.1007/978-3-030-05405-2

[9] Conway D., Hulme M. The impacts of climate variability and future climate change in the Nile Basin on water resources in Egypt. International Journal of Water Resources Development 1996:12(3):277-296. https://doi.org/10.1080/07900629650178

[10] Smith J., et al. Potential impacts of climate change on the Egyptian economy. Cairo, 2013.

[11] Masria A., et al. Coastal zone issues: A case study (Egypt). Procedia Engineering 2014:70:1102-1111. https://doi.org/10.1016/j.proeng.2014.02.122

[12] El-Nahry A. H., Doluschitz R. Climate change and its impacts on the coastal zone of the Nile Delta, Egypt. Environmental Earth Sciences 2010:59:1497-1506. https://doi.org/10.1007/s12665-009-0135-0

[13] Crippa M., et al. Fossil CO2 and GHG emissions of all world countries. Luxembourg: Publications Office of the European Union 2019:105:1867-1877. https://doi.org/10.2760/687800

[14] General Authority for Urban Planning. Development Strategy for the Governorates of the Republic: Delta Region (Dakahlia, Damietta, Kafr El-Shiekh, Monufia and Gharbia). Egypt: GOPP, 2008.

[15] Central Agency for Public Mobilization and Statistics. Annual Bulletin of Electricity and Energy Statistics 2015/2016. Egypt: CAPMAS, 2017.

[16] Abdelhamid E., Shaker A. N. Egypt Population, Housing, and Establishments Census 2017. Egypt: CAPMAS, 2017.

[17] Arouri M. E. H., et al. Energy consumption, economic growth and $\mathrm{CO}_{2}$ emissions in Middle East and North African countries. Energy Policy 2012:45:342-349. https://doi.org/10.1016/j.enpol.2012.02.042

[18] Sozer H. Improving energy efficiency through the design of the building envelope. Building Environment 2010:45(12):2581-2593. https://doi.org/10.1016/j.buildenv.2010.05.004

[19] Mardiana A., Riffat S. B. Building Energy Consumption and Carbon dioxide Emissions: Threat to Climate Change. Journal of Earth Science \& Climatic Change 2015:3:1-3. https://doi.org/10.4172/2157-7617.s3-001

[20] Edenhofer O., et al. Climate Change 2014: Mitigation of Climate Change. Contribution of Working Group III to the Fifth Assessment Report of the Intergovernmental Panel on Climate Change. Cambridge University Press, 2014.

[21] Ürge-Vorsatz D., et al. Mitigating $\mathrm{CO}_{2}$ emissions from energy use in the world's buildings. Building Research and Information 2007:35:379-398. https://doi.org/10.1080/09613210701325883

[22] Santamouris M., Asimakopoulos D. Passive cooling of buildings. Earthscan, 1996.

[23] Al-Homoud M. S. The Effectiveness of Thermal Insulation in Different Types of Buildings in Hot Climates. Journal of Building Physics 2004:27(3):235-247. https://doi.org/10.1177/1097196304038368

[24] El-Megharbel N. Sustainable Development Strategy: Egypt's vision 2030 And Planning Reform. Egypt: Ministry of Planning, 2015.

[25] HBRC. Egyptian Code for Improving the Efficiency of Energy Use in Buildings, Part 1: Residential Buildings, ECP306-2005. Arab Republic of Egypt: Ministry of Housing, 2008. (In Arabic)

[26] Ministry of Housing, Utilities and Urban Development. Egyptian Green Pyramid Rating System, For New Buildings and Major Renovation. Arab Republic of Egypt: MHUC, 2018.

[27] Schlueter A., Geyer P. Linking BIM and Design of Experiments to balance architectural and technical design factors for energy performance. Automation in Construction 2018:86:33-43. https://doi.org/10.1016/j.autcon.2017.10.021

[28] Faenø T., et al. Building Performance Simulation tools for planning of energy efficiency retrofits. Proceedings of the $10^{\text {th }}$ Nordic Symphosium on Building Physics, 2014

[29] Abouaiana A. Abouaiana_ECT_2021_Simulation_Model. 2021. https://doi.org/10.13140/RG.2.2.27517.59361

[30] Ministry of Housing, Utilities and Ürban Communities. Building Materials Price Bulletin, December 2020. Arab Republic of Egypt: MHUC, 2020. (in Arabic)

[31] Fan Y., Xia X. A multi-objective optimization model for energy-efficiency building envelope retrofitting plan with rooftop PV system installation and maintenance. Applied Energy 2017:189:327-335. https://doi.org/10.1016/j.apenergy.2016.12.077

[32] Verbeeck G., Hens H. Energy savings in retrofitted dwellings: economically viable? Energy and Buildings 2005:37(7):747-754. https://doi.org/10.1016/j.enbuild.2004.10.003

[33] Kaynakli O. A review of the economical and optimum thermal insulation thickness for building applications. Renewable and Sustainable Energy Reviews 2012:16(1):415-425. https://doi.org/10.1016/j.rser.2011.08.006

[34] Albadry S., Tarabieh K., Sewilam H. Achieving net zero-energy buildings through retrofitting existing residential buildings using PV panels. Energy Procedia 2017:115:195-204. https://doi.org/10.1016/j.egypro.2017.05.018

[35] Mata É., Kalagasidis A. S., Johnsson F. Cost-effective retrofitting of Swedish residential buildings: effects of energy price developments and discount rates. Energy Efficiency 2015:8:223-237. https://doi.org/10.1007/s12053-014-9287-1

[36] Remer D. S., Nieto A. P. A compendium and comparison of 25 project evaluation techniques. Part 1: Net present value and rate of return methods. International Journal of Production Economics 1995:42:79-96.

https://doi.org/10.1016/0925-5273(95)00104-2 
[37] Schweser K. Schwesernotes 2019 Level I Cfa ${ }^{\circledR}$ Book 1: Ethical And Professional Standards And Quantitative Methods. USA: Kaplan Inc., 2018.

[38] Egyptian Central Banks key rates. Interest rates fall in Egypt [Online]. [Accessed 17.01.2021]. Available: https://countryeconomy.com/keyrates/egypt\#: :text=Interest\%20rates\%20fall\%20in\%20Egypt,or\%20a\%20possible\%20deflationary\%20situation

[39] Calculat Stuff. Net Present Value [Online]. [Accessed 17.01.2021]. Available: https://www.calculatestuff.com/financial/npv-calculator

[40] Fathy H. Architecture of The Poor: Experience in Rural Egypt. Cairo: American University in Cairo, 1989. (In Arabic)

[41] Tzortzopoulos P., et al. Evaluating social housing retrofit options to support clients' decision making-SIMPLER BIM protocol. Sustainability 2019:11(9):2507. https://doi.org/10.3390/su11092507

[42] Synnefa A., et al. Transformation through renovation: An energy efficient retrofit of an apartment building in Athens. Procedia Engineering 2017:180:1003-1014. https://doi.org/10.1016/j.proeng.2017.04.260

[43] Becchio C., Bottero M.C., Corgnati S.P., Dell'Anna F. Evaluating Health Benefits of Urban Energy Retrofitting: An Application for the City of Turin. In: Bisello A., Vettorato D., Laconte P., Costa S. (eds) Smart and Sustainable Planning for Cities and Regions. Springer, Cham., 2018. https://doi.org/10.1007/978-3-319-75774-2

[44] Balest J., Vettorato D. Social Acceptance of Energy Retrofit in Social Housing: Beyond the Technological Viewpoint. Smart and Sustainable Planning for Cities and Regions. Springer International Publishing, 2018.

[45] Larroumet A. Training guide. Social Acceptance Developing dialogue with your stakeholders: Applying social acceptance tools to avoid barriers in biobased projects, 2018.

[46] The questionnaire [Online]. [Accessed 24.01.2021]. Available: https://docs.google.com/forms/d/e/1FAIpQLSdOYTUcvkUEJXdMvsmshTWTQrnasvDASZScWlSbh_gV39a7hQ/vi ewform?fbclid=IwAR0VYabmIl4LX16lbtrRNp7ikIwRsTkRQIQPjsT9jiddelI1OSkh291jMbE (In Arabic) 